\title{
RESENHAS/BOOK REVIEWS
}

Beard, Mary. Women \& Power: a Manifesto. Liveright Publishing Corporation, 2017. Mary Beard's Women and Power: Dialogues with Tradition and the Search for a Woman's Sentence.

By Davi Pinho ${ }^{1^{*}}$

Marcela Santos Brigida ${ }^{2 * *}$

${ }^{1,2}$ Universidade do Estado do Rio de Janeiro, Rio de Janeiro, Rio de Janeiro, Brasil

In Women and Power: A Manifesto, Mary Beard presents her readers with a thorough analysis of the ways in which the silencing of women has been undertaken as a norm in Western history and how that practice has culminated in their exclusion from power. Their silencing has been operated in manifold ways; from the verbal admonishing of men who alert women that their speaking in public is improper, through the physical removal of their tongues, up to the practice of quite simply not taking women seriously, something that Beard dubs the "Ms. Triggs Question", a reference to a cartoon that alludes to that practice in corporate environments - "That's an excellent suggestion, Miss Triggs. Perhaps one of the men here would like to make it", it says. Among the many paths Beard could have pursued to address the question of women and power, she chose to explore the treatment women received in the Classical Tradition. The fact that Professor Beard is a world-renowned classicist whose books continue to be of seminal reference for Anglophone scholars of the Greek and Roman Classical Traditions has sparkled intense debates over her successful endeavour to revisit the past through the lenses of feminism. From the outset, it is a pleasure to have the doors of Antiquity opened to us readers by someone like Professor Beard. Anyone who ventures to engage with her text, be it a scholar or someone from a wider public that might not have come into contact with Aristophanes or Aeschylus, will come out with the valuable experience of realising that, knowingly or not, we are contemporary to ideas that have been present in the past and vice versa.

\footnotetext{
"Professor of English Literature at Universidade do Estado do Rio de Janeiro (UERJ). He is the author of Imagens do feminino na obra e vida de Virginia Woolf (Brazil, 2015) and co-editor of Eros, Tecnologia, Transumanismo (Brazil, 2015), Conversas sobre Literatura em Tempos de Crise (Brazil, 2017) and Literaturas de Lingua Inglesa: Leituras Interdisciplinares (Brazil, 2017). He has published several essays, articles and book chapters on Virginia Woolf and her lasting influence on world writers. His e-mail address is davi.pinho@uerj. br. Orcid: 0000-0003-3438-1895.

${ }^{*}$ Holds a BA in English (UERJ, 2017) and is currently reading for her MA in English Literature at UERJ, where her research is funded by CAPES. She works on contemporary appropriations and remediations of Emily Dickinson’s oeuvre. Her e-mail address is marcelascastelli@gmail.com. Orcid: 0000-0002-0951-1603.
} 
Women and Power, Beard tells us, was based on two lectures she delivered in 2014 and 2017. While the author speaks of the difficulties and peculiarities of translating lectures to the written form, similarities between Professor Beard's essay and an influential text not only in the context of feminist criticism, but also of modernist English Literature, Virginia Woolf's A Room of One's Own (1929), become apparent. Woolf begins her text by addressing her audience, stating that when she was asked to speak about women and fiction she "sat down on the banks of a river and began to wonder what the words meant", as the title "women and fiction" may be understood - and approached - in many ways, not unlike Beard's pairing of women and power. Both women choose a specific point to discuss and analyse. Woolf, of course, argues that a woman "must have money and a room of her own if she is to write fiction" and then proceeds to unpack her thesis employing semi-fictional scenarios revolving around "Oxbridge" and "Fernham" and the ways in which the absence of women in the literary tradition makes it more difficult for modern women writers to find a sentence they can make use of, a sentence of their own that, while somewhat distinct from the masculine sentence, the sentence of canonized tradition, of the public sphere and scholarly learning, does not revolve around the social constraints of its speaker. When it does, bitterness impedes the writer of writing of the thing itself and, instead of producing real fiction, the woman who holds the pen focuses on using fiction to denounce the evils of patriarchy, thus stalling yet again the establishment of the woman's sentence as a fiction writer. Fiction, to Woolf, presents the fracture between History and Literature, and the word "woman" allows her to fill this void with images that have the potentiality to relocate empirical women from the margins to semi-central positions. In this sense, she too is considering how power excludes and incorporates "woman", the word and the body. Therefore, it is by turning to the literary tradition and the social contexts that surround it and the voices it elects as part of its canon that Woolf structures her text and tells her readers that it is quite understandable that in ages where women were locked up, beaten and flung about the room, they were not quite able to provide their modern heirs neither with an established written tradition nor with the practical elements needed in order to secure a woman's freedom: enough money to get by and a room of her own to write without interruptions.

Turning to Woolf's essay-manifesto provides us with an interesting stance to study the way in which Beard chose to structure her text. Like Woolf, she eschews from offering a fixed conclusion or a "nugget of pure truth" (Woolf, 1929, p. 3). Instead, the professor analyses representations of women in classical literature as stances where the tense relationship between gender and power allows us to understand how the societies in which those works were produced looked at women and where they thought their place should be. If in ancient times women's right to speak - and here the relationship between power and discourse becomes clearer - has been extremely limited, Beard's analysis shows that the way public women are treated in social media in our age in comparison to their male counterparts is abhorrent to say the least, for their right to being listened to is in no way a given. In that sense, the author seeks 
to trace the silencing mechanisms that rest embedded in Western culture and work towards the exclusion of women from centres of power.

Beard's timely study begins by addressing the "first recorded example of a man telling a woman to 'shut up'" in Western literature (p. 7). Telemachus tells Penelope in Homer's Odyssey that her voice is not to be heard in public, she should go back inside the house and let him, now a grown man, deal with the issue at hand. Public discourse was part of the coming of age of the male members of society. Beard then goes on to tell us of a Roman woman of the first century AD who could escape her condition of not being fit to speak in the forum because, according to a Roman anthologist, "she really had a man's nature behind the appearance of a woman" and was thus called "the 'androgyne" (p. 19). Other examples of this sort of hybrid women, not perceived as being women per se, are presented throughout the essay. We learn, for instance, that although Athenian drama and other classical literatures in general are filled with women we now perceive as strong, such as Medea, Clytemnestra and Antigone, they are not presented as role models, but as usurpers of power whose actions beget chaos. They are not, Beard tells us, women in the Greek sense, but "monstrous hybrids" (p. 34). Even the image of the goddess Athena, born from the head of Zeus, appears as a fantasy of an ideal world where women would be dispensable even in relation to their main function in society: procreation. Other examples of exceptions where women were allowed to speak in the public arena in Antiquity would be if they were to do so as victims or martyrs or if they were speaking for other women: never for the whole of society. Thus, as a result of this power dynamics centred around those who can and those who cannot speak, women could only represent themselves as "women" - a word formulated without them, which is marked by misogynous ideas of sex -, while men could speak on behalf of humanity. The interesting implication here is that, through public speaking and oratory, men have managed to fix women's identity as marginal to the establishment of a human community, since men are the only ones who can access the word in order to represent the interests of humanity. This understanding lifts the neutral veil over the word "humanity" and traces the gendered layers that inform the speaking citizen in the Classical Tradition.

By consequence, Beard tells us, the modern techniques of rhetoric that became prominent in the Renaissance were drawn from Antiquity. The issue of the license for women to speak in public only addressing niched interests remains - albeit in a veiled way - when one looks at modern traditions of oratory. Interestingly, Beard draws parallels with English politics: while it is more socially acceptable for a woman to be Minister of Women or of Education or Health, no woman has ever been Chancellor of the Exchequer. So here, once more, Beard's text echoes Woolf's: if women writers needed a sentence that was theirs instead of attempting to replicate men's sentence or even try to annihilate it, it is also necessary to create structures of power where women are neither niched nor compelled to emulate features of male politicians. The pressing question in Beard, thus, is one that was also crucial to Woolf: how to 
become a speaking subject without falling prey to destruction mechanisms, where every subject needs to obliterate an object. Can an object speak?

The fact that women are often not taken seriously, regardless of their views, especially in spaces perceived as being traditionally male, appears as one of the most problematic issues for Beard, and one she explores most alertly. The critic says she has lost count of the number of times she has been called "an ignorant moron" and that a Twitter user felt at liberty to lecture her on Roman history. Those occurrences point to the fact that it is not what women say that prompt abuse; controversial or not, it is the fact they are saying anything at all that begets the onslaught. Here, once again the image of the classical "androgyne" resurfaces: the few women who manage to be heard consciously appropriate male rhetorics or even physical features perceived as male: as we have no template for what a powerful woman looks like, Beard says, the image commonly attributed to one is that she would resemble a man, be it through her wearing of trouser suits - such as Angela Merkel and Hillary Clinton - or even through the neutering of what is perceived as being too deviant from the male standard. Margaret Thatcher took on voice training to lower the pitch of her voice, as her advisers alerted her that would make her sound more like an authority. The issue with those measures women feel compelled to take even today, an era we like to think of as progressive in Western culture, is that women remain as mere impersonators of the male sentence, as Woolf would put it, still severely lacking a rhetorical role that belongs to them. Beard then urges her readers to think about the fault-lines in the dominant male discourse in order to find what is wrong with it, as she defends that if women are still outcasts within the structures of power, it is not women that need to change; it is our notion of power that is lacking and needs redefining to accommodate different models.

Finally, with no attempt at what Woolf sardonically coined a "nugget of pure truth", surely mocking academics who set out to produce those, Beard tries to offer her views on what could be done collectively to improve the structures of power she criticizes. The author urges her readers to start thinking about power in different, more democratic ways: "it means thinking collaboratively, about the power of followers not just of leaders" (p. 51), she tells us. It is not easy to subvert millenarian structures of power that, in one way or another, have naturalised women's enforced and surveilled muteness. From Telemachus' silencing of Penelope in Homer's Odyssey to the memes showing Donald Trump as Perseus holding the severed head of Hillary Clinton as Medea, civilizations have risen and fallen; the ways in which the silencing is implemented has changed, but the practice remains strong. At the end of her urgent essay, what Mary Beard asks of her readers is that they think of new ways of approaching power not as a possession, but as an attribute or even a verb. That is, power must be regarded in a way that makes it accessible to women not only within the structure of state politics, but also in day to day life. If this becomes our task, one day, when Miss Triggs makes a valid point, she will be praised for herself, instead of it being a cause of embarrassment, for she is not "one of the guys". If Woolf's modernist 
utopia foresees a way out through an androgynous sentence, one that combines the man's and the woman's sentences into a broader, more liberating one, accessible to all, Beard too seems to wish for the same when she approaches language as a source of power, even if the word "androgyny" is refuted due to its historical dimension. A comparative study of how Beard's text unearths androgyny and how it is framed in Woolf's A Room of One's Own would make for interesting critical transits between these two manifestoes, for Woolf repositions the feminine as access to the androgyne, not the other way around, reclaiming and reappropriating the tradition that has placed Andros before Gynos. In this sense, Beard and Woolf supplement one another in their critique of power itself. If Woolfian thought indicates the feminine as what exceeds the way power is articulated to the axis of identity, Beard urges us, as a society, to look for alternative ways to look at and understand power so that it ceases to function in the one-gendered age-old microphysics that produces silencing and alienation. We must do better, Beard ultimately tells us, and we must do it so ourselves.

\section{References}

WOOLF, Virginia. A Room of One’s Own. 1929. Oxford University Press, 1992. 